\title{
MODEL MANAJEMEN MUTU BAGI BAZNAS DAN LAZ DI INDONESIA
}

\author{
Kuntarno Noor Aflah \\ Institut Agama Islam Negeri (IAIN) Kudus \\ e-mail: aflah@stainkudus.ac.id
}

\begin{abstract}
This study aims to find out the quality management models used by National Zakat Board (BAZNAS) and the Institute for Amil Zakat (LAZ) in Indonesia. This study uses qualitative descriptive method with literature review as the main study material. The results of the study show that there are several models and forms of quality management selected by zakat management organizations in Indonesia. Most choose ISO as a reference in testing the performance quality of their institutions. This choice is taken because it tends to be more familiar among the people and has been used in companies in Indonesia even in the world. Zakat Forum introduces other quality management models besides ISO, namely Zakah Criteria for Performance Exellence. This model is considered more suitable with the characteristics of zakat, because it can identify the strengths and weakness as a whole with reference to the seven criteria. The basic value and framework of this quality management model is based on the Qur'an and hadith so that it is more Islamic.
\end{abstract}

Keywords: Quality Management, BAZNAS, LAZ, Quality Criteria 


\section{Kuntarno Noor Aflah}

\section{Pendahuluhan}

Manajemen mutu bagi organisasi profit merupakan suatu hal penting untuk diterapkan. Dengan menerapkan manajemen mutu maka kepercayaan (trust) masyarakat dan konsumen akan semakin meningkat. Sebaliknya, organisasi profit yang tidak menerapkan manajemen mutu, kepercayaan masyarakat bisa menjadi rendah. Organisasi yang menerapkan manejemen mutu secara baik dan benar maka ia telah menjadi organisasi yang terpercaya (trustable institution) (INFOZ, 20: 2011).

Kinerja organisasi profit yang sudah menerapkan manajemen mutu berbeda dengan kinerja organisasi yang belum menerapkan manajemen mutu. Mereka yang sudah menerapkan manajemen mutu, sistem kerjanya tertata rapi berdasar atas juklak dan juknis yang baku. Semua yang dilakukan di organisasi profit (perusahaan) tersebut, memiliki pedoman dan standar prosedur yang tetap. Ini menujukkan bahwa para pemimpinnya memahami bahwa membangun suatu sistem itu lebih penting dibandingkan membangun aspek lainnya, seperti aspek top leader atau pemimpin.

Pemimpin boleh berganti berkali-kali namun sistem harus baku dan menjadi pedoman dan landasan dalam operasionalisasi organisasi untuk kurun waktu yang tidak terbatas. Selama sebuah sistem itu masih sesuai dengan visi misi dan tujuan organisasi maka akan terus dipertahankan.

Bagaimana dengan manajemen mutu bagi organisasi non profit seperti organisasi pengelola zakat (OPZ)? Ternyata manajemen mutu bagi OPZ juga sangat penting. Malah bisa dibilang jauh lebih penting, karena di dalam OPZ aspek-aspek manajemen yang perlu diatur dan distandarisasikan jauh lebih banyak dibandingkan aspekaspek yang ada dalam organisasi profit. Jika pihak yang terkait dalam organisasi profit hanya pemasok dan 
pelanggan, maka di dalam OPZ tidak hanya itu. Stakeholder pada OPZ meliputi muzakki (orang yang membayar zakat), mustahik (orang yang menerima zakat), amil (orang yang mengelola zakat), pemerintah, dan masyarakat umum yang nota bene mereka belum masuk kategori muzaki, mustahik dan juga amil (pengelola zakat) (Bambang Sudibyo, dkk, 2017).

Di sisi lainnya perlu diperhatikan lagi dari aspek pengaturan fikihnya yang memiliki ketentuan yang harus ditaati. Berbagai macam pendapat dari ulama fikih dan pendapat madzhab, juga perlu menjadi pertimbangan yang tidak bisa dibiarkan begitu saja. Sedangkan kondisi praktik di lapangan, pengelolaan zakat menuntut amil mampu menyesuaikan antara aturan fikih dengan kondisi lapangan. Seperti misalnya, mekanisme penyaluran dan pendistribusian zakat. Di dalam syariat zakat hanya disebutkan ada sebanyak 8 golongan penerima zakat, yaitu fakir, miskin, amil, muallaf, riqob (hamba sahaya), gharim, sabilillah, ibnu sabil. Siapa mereka yang termasuk dalam kategori ini, apa saja kriterianya dan dalam bentuk apa mereka mendapatkan zakat, ini perlu "ijtihad" tersendiri oleh amil, sebagai pihak pengelola (Didin Hafidhuddin, 2007).

Amil harus mampu mengelola zakat dan menyalurkannya dalam bentuk program-program pemberdayaan dan pendayagunaan yang kreatif dan inovatif. Bukan hanya dalam bentuk program-program biasa seperti membagi-bagikan santunan, memberikan uang dan bentuk-bentuk lainnya yang konvensional dan konsumtif, melainkan dalam bentuk terobosan programprogram yang bersifat produktif (Didin Hafidhuddin, 2012).

Seluruh aspek-aspek pengelolaan zakat sebagaimana disebutkan di atas diperlukan pengaturan secara profesional dan terarah serta memiliki panduan baku yang ditetapkan 


\section{Kuntarno Noor Aflah}

oleh organisasi untuk tujuan jangka panjang yang ingin dicapai.

Kita tahu bahwa jenis organisasi nirlaba sangat banyak. Masing-masing memiliki karakteristik yang berbeda-beda. Ada jenis organisasi nirlaba yang core competence-nya sosial murni, ada juga organisasi nirlaba yang berbasis sosial keagamaan, di mana aspek-aspek sosial dan nilai-nilai keagamaan menjadi landasannya. OPZ sebagai organisasi nirlaba yang berbasis keagamaan dan core competence-nya di bidang zakat, infak dan shadaqah, memiliki karakteristik yang spesifik, di mana pengaturan dalam pengelolaannya harus mengacu pada kaidah-kaidah fikih.

Adanya perbedaan core competence itu dapat mempengaruhi kecenderungan organisasi untuk memilih jenis standarisasi manajemen mutu yang ada. Mereka bisa memilih jenis-jenis standarisasi, seperti Six Sigma, Balance Scorcade, ISO dan lainnya. Kemudian, bagaimana dengan Organisasi Pengelola Zakat, apakah perbedaan karakteristik dan core competence memiliki kecenderungan memilih jenis standarisasi mutu. Apakah sudah tersedia standarisasi mutu yang dikhususkan bagi Organisasi Pengelola Zakat (INFOZ, 2011).

Melihat pentingnya manajemen mutu bagi OPZ di Indonesia, serta berdasarkan gambaran kondisi permasalahan di atas, penulis tertarik meneliti dan mengkaji lebih mendalam tentang apa jenis standar mutu yang dijadikan pegangan bagi $\mathrm{OPZ}$, apa prinsip-prinsip yang digunakan dalam manajemen mutu bagi OPZ. Apakah ada perbedaan antara manajemen mutu yang digunakan oleh OPZ dengan manajemen mutu yang digunakan oleh organisasi profit, bagaimana urgensi manajemen mutu bagi OPZ untuk mengukur kepercayaan masyarakat sehingga menjadi organisasi yang dipercaya (trustable institution). 
Siapa saja OPZ di Indonesia yang sudah menerapkan standarisasi manajemen mutu, dengan tema "Model Manajemen Mutu Bagi BAZNAS dan LAZ di Indonesia".

\section{Pembahasan}

\section{Profesionalisme pengelolaan zakat}

Jika dicermati secara seksama, saat ini masih banyak organisasi pengelola zakat yang keberadaannya hanya sekedar menjalankan aktifitas mengumpulkan dan menyalurkan zakat. Sebagai bagian akhir dari hasil pengumpulannya, kemudian didistribusikan kepada mustahik. Hanya sebatas itu. Permasalahannya kemudian adalah, pola dan cara seperti itu terjadi berulang-ulang terus menerus dari tahun ke tahun. Hal ini jika dipertahankan tanpa ada upaya peningkatan manajemen mutu dan kinerja yang terintegrasi dengan bersandar pada kebutuhan muzaki, mustahik dan stakeholder, maka menjadi kurang bermakna. Aktifitas pengelolaan zakat tak lebih dari sekedar bagi-bagi bantuan layaknya seperti pemberian bantuan organisasi lainnya. Dengan begitu semua pihak tidak bisa mendapatkan value yang berarti dari keberadaan organisasi pengelola zakat. Zakat yang seharusnya bisa dikelola dengan profesional dan mampu menggerakkan potensi ekonomi dan mengangkat derajat kaum dhuafa, menjadi kurang bermakna (Noor Aflah, 2010).

Saat ini masih ada orang mengira mengelola zakat itu mudah, tidak perlu strategi dan perencanaan yang matang. Tidak usah dikelola secara professional, apalagi sampai membandingkan dengan manajemen dan model pengelolaan dana di organisasi profit, karena karakter zakat tidak lebih dari sebuah kegiatan sosial yang dikumpulkan dari orang kaya lalu dibagikan kepada orang yang membutuhkan (Noor Aflah, 2012). 


\section{Kuntarno Noor Aflah}

Anggapan seperti itu jika diterapkan di masa lampau mungkin benar. Namun, jika ditarik pada masa sekarang, ini jelas tidak tepat. Karena pengelolaan zakat di Indonesia, terutama sejak masuk ke ranah negara, yakni sejak dikeluarkannya UU pertama tahun 1999, hingga dirubah menjadi UU tahun 2011, mengalami perubahan yang sangat signifikan. Jika sebelumnya zakat hanya dikelola oleh kepanitiaan di masjid dan mushala, atau oleh sebagian muzaki (orang yang sudah berkewajiban zakat) yang di kelola (dibagikan) sendiri, sekarang sudah dikelola secara modern dan profesional melalui pendirian badan hukum dan organisasi tersendiri. Perangkat yang digunakan juga serba mengikuti perkembangan zaman (Noor Aflah (ed), 2010).

Jika dulu zakat tidak menjadi sesuatu yang menarik untuk dilirik, kini zakat seperti gadis cantik yang hampir semua orang terpikat ingin mengelolanya. Hal ini terbukti semakin hari semakin banyak jumlah organisasi pengelola zakat (OPZ) yang lahir. Hingga tahun 2018 ini jumlah BAZNAS, LAZ dan UPZ yang resmi dan legal dikukuhkan oleh pemerintah adalah sebanyak 615 lembaga, baik pemerintah maupun swasta. Dengan rincian, 1 Baznas, 33 Baznas Provinsi, 445 Baznas Kabupaten/Kota, 17 LAZ Nasional, 11 LAZ Provinsi, 7 LAZ Kabupaten/Kota, 101 UPZ Baznas (Kuntarno Noor Aflah, 2018).

Maraknya pertumbuhan organisasi pengelola zakat bisa jadi sebuah indikasi positif. Karena jika dilihat antara potensi zakat dan realisasi penghimpunan zakat di Indonesia, masih terjadi gap yang sangat jauh. Potensi zakat yang perkirKn mencapai Rp 217 triliun per tahun, baru terkumpul Rp 5 triliun (Kuntarno Noor Aflah, 9: 2018). Artinya, masih besar 'kue' potensi zakat yang belum tergali. Masih tersimpan kekuatan hebat zakat yang apabila terhimpun dengan baik, dapat membantu kemiskinan di 
Indonesia yang jumlahnya mencapai 26 juta orang lebih. (BPS, 2018)

Namun yang menjadi pertanyaan, apakah dengan banyaknya jumlah OPZ di Indonesia akan menjadi solusi untuk mendongkrak pengumpulan zakat? Apa syarat untuk menjadi organisasi zakat yang benar sudah dipenuhi sehingga berjalan sesuai rel syariat dan manajemen (organisasi dan keuangan) yang berlaku? Ataukah sekadar euphoria mendirikan lembaga zakat. Yang harus diperhatikan, syarat utama mendirikan lembaga zakat adalah amanah dan profesional.

Mana yang lebih baik; apakah sedikit OPZ tapi berkualitas atau banyak tapi tidak berkualitas, atau banyak tapi berkualitas? Pilihan seperti inilah yang kemudian menjadi salah satu alasan lahirnya Undang-Undang No. 23 tahun 2011.

Pada zaman yang kian canggih dan moderen seperti sekarang ini, begitu banyak tawaran yang diberikan berbagai kalangan profesional guna meningkatkan manajemen dan mutu kinerja sebuah lembaga atau organisasi. Sebut saja misalnya, ada Six Sigma, ISO, Balance Scorcade dan lain-lain. Semua menawarkan yang terbaik. Di Indonesia sendiri yang paling banyak terdengar gaungnya adalah ISO.

\section{Sistem manajemen mutu}

Selama ini, sistem manajemen mutu yang dikenal di publik salah satunya adalah ISO. ISO (International Organization for Standardization) adalah badan penetap standar internasional yang terdiri dari wakil-wakil dari badan standardisasi nasional setiap negara. Mulanya singkatan dari nama lembaga tersebut adalah IOS, bukan ISO. Tetapi sekarang lebih sering memakai singkatan ISO, karena dalam bahasa Yunani, isos berarti sama (equal). ISO 


\section{Kuntarno Noor Aflah}

didirikan pada 23 Februari 1947 yang berfungsi menetapkan standard-standard industrial dan komersial dunia. ISO, yang merupakan lembaga nirlaba internasional, pada awalnya dibentuk untuk membuat dan memperkenalkan standardisasi internasional untuk apa saja. Standar yang sudah kita kenal antara lain standar jenis film, fotografi, ukuran kartu telepon, kartu ATM, ukuran dan ketebalan kertas dan lainnya. Dalam menetapkan suatu standar tersebut mereka mengundang wakil anggotanya dari 130 negara untuk duduk dalam Komite Teknis (TC), Sub Komite (SC) dan Kelompok Kerja (WG). (https:/ / isokonsultindo.com/8prinsip-manajemen-mutu)

Meski ISO adalah organisasi non pemerintah, kemampuannya untuk menetapkan standar yang sering menjadi hukum melalui persetujuan atau standard nasional membuatnya lebih berpengaruh daripada kebanyakan organisasi non-pemerintah lainnya, dan dalam prakteknya ISO menjadi konsorsium dengan hubungan yang kuat dengan pihak-pihak pemerintah. Peserta ISO termasuk satu badan standar nasional dari setiap negara dan perusahaanperusahaan besar.

ISO 9001:2015 adalah suatu standar internasional untuk sistem manajemen Mutu (kualitas). ISO 9001:2015 menetapkan persyaratan-persyaratan dan rekomendasi untuk desain dan penilaian dari suatu sistem manajemen mutu. ISO 9001: 2015 bukan merupakan standar produk, karena tidak menyatakan persyaratan-persyaratan yang harus dipenuhi oleh sebuah produk (barang atau jasa). ISO 9001:2015 hanya merupakan standar sistem manajemen kualitas. Namun, bagaimanapun juga diharapkan bahwa produk yang dihasilkan dari suatu sistem manajemen kualitas internasional, akan berkualitas baik (standar).

Sehingga dapat disimpulkan bahwa Quality Management Systems (ISO 9001: 2015) adalah merupakan 
prosedur terdokumentasi dan praktek-praktek standar untuk manajemen sistem, yang bertujuan menjamin kesesuaian dari suatu proses dan produk (barang atau jasa) terhadap kebutuhan atau persyaratan tertentu, dimana kebutuhan atau persyaratan tertentu tersebut ditentukan atau dispesifikasikan oleh pelanggan dan organisasi (www.alimansur.wordpress.com).

Manfaat Penerapan ISO 9001: 2015 adalah: 1) Meningkatkan Kepercayaan Pelanggan, 2) Jaminan Kualitas Produk dan Proses, 3) Meningkatkan Produktivitas perusahaan \& "market gain", 4) Meningkatkan motivasi, moral \& kinerja karyawan, 5) Sebagai alat analisa kompetitor perusahaan, 6) Meningkatkan hubungan saling menguntungkan dengan pemasok, 7) Meningkatkan cost efficiency \& keamanan produk, 7) Meningkatkan komunikasi internal, 8) Meningkatkan image positif perusahaan, 9) Sistem terdokumentasi, 10) Media untuk Pelatihan dan Pendidikan.

Penerapan standar mutu ISO dalam suatu perusahaan memegang peranan yang cukup penting, apalagi bagi perusahaan manufaktur yang memiliki pasar yang cukup luas. Terkadang pasar meminta produk yang sudah berstandar internasional. Penerapan ISO bukan hanya sekedar mengumpulkan dokumen-dokumen pendukung, yang memang harus disediakan, melainkan penerapan langsung pada sistem yang ada dalam perusahaan. Dimulai dari sistem administrasinya, sistem produksinya, deliverynya, hingga after sales service-nya. Semua harus memenuhi standar yang diterapkan.

Di Indonesia terdapat satu standar mutu nasional, yang biasa kita kenal SNI. Standar Nasional Indonesia (disingkat SNI) adalah satu-satunya standar yang berlaku secara nasional di Indonesia. SNI dirumuskan oleh Panitia Teknis dan ditetapkan oleh BSN (Badan Standarisasi 


\section{Kuntarno Noor Aflah}

Nasional). Standar ini digunakan untuk men-standarkan produk masal yang nantinya akan digunakan oleh semua orang (Vincent Gasperz, 2008).

Coba perhatikan produk-produk seperti Helm, Tabung Gas LPG, konstruksi bangunan, dan masih banyak lagi, biasanya terdapat logo SNI. Artinya adalah produkproduk tersebut telah lulus uji standar nasional. Inti dari penarapan standar mutu adalah terjaganya kualitas hasil dari suatu produk. "Do what you write and write what you do".

Semacam suatu sistem knowledge sharing yang memungkinkan setiap orang untuk menghasilkan yang sama dengan kualitas yang sama pula. Sehingga akan mengurangi ketergantungan terhadap satu orang saja (Vincent Gasperz, 2007).

\section{Kriteria standar mutu}

Standar sendiri bisa didefiniskan sebagai kesepakatan-kesepakatan yang telah didokumentasikan yang di dalamnya terdiri antara lain mengenai spesifikasispesifikasi teknis atau kriteria-kriteria yang akurat yang digunakan sebagai peraturan, petunjuk, atau definisidefinisi tertentu untuk menjamin suatu barang, produk, proses, atau jasa sesuai dengan yang telah dinyatakan. Salah satu contohnya adalah penetapan standar ukuran dan format kartu kredit, atau kartu-kartu "pintar" (smart) lainnya yang telah mengikuti standar internasional ISO dan dapat digunakan di berbagai mesin anjungan tunai mandiri (ATM) di seluruh dunia, dan banyak contoh-contoh lainnya. Dengan demikian standar internasional telah membantu kehidupan manusia menjadi lebih mudah, serta lebih meningkatkan keandalan dan kegunaan barang dan jasa.

Penerapan ISO di suatu perusahaan atau lembaga memiliki berbagai kegunaan antara lain; meningkatkan citra perusahaan, meningkatkan kinerja lingkungan perusahaan, 
meningkatkan efisiensi kegiatan, memperbaiki manajemen organisasi dengan menerapkan perencanaan, pelaksanaan, pengukuran dan tindakan perbaikan (plan, do, check, act), meningkatkan penataan terhadap ketentuan peraturan perundang-undangan dalam hal pengelolaan lingkungan, mengurangi risiko usaha, meningkatkan daya saing, meningkatkan komunikasi internal dan hubungan baik dengan berbagai pihak yang berkepentingan, mendapat kepercayaan dari konsumen/mitra kerja/pemodal dan seterusnya (Syahu Sugian O, 2007)

Hingga kini ISO sudah melahirkan kurang lebih sekitar 25 ribu standardisasi. Tetapi tak semuanya dikenal luas, hanya ada beberapa ISO yang dikenal. Salah satu ISO yang paling populer adalah ISO 9001 yang merupakan standard manajemen mutu. Selain itu ISO 14000 yang mengukur standard manajemen lingkungan, serta ISO 2000 tentang pangan. Ketiganya adalah ISO yang paling dikenal.

Meski demikian urgensi penerapan ISO itu tergantung dari kemauan organisasi itu sendiri jika perusahaan ingin menerapkan efisiensi dan mencapai kinerja terbaiknya maka tentu ISO menjadi perkara yang tak bisa ditawar. Karena menjadi sangat urgen. Tetapi manakala lembaga tersebut merasa hal-hal itu tidak perlu maka ISO bisa diabaikan. Namun acapkali adopsi ISO menjadi keniscayaan manakala menjadi permintaan dari kastamer karena keinginan mereka terhadap suplay produk yang berkualitas. Sebab dalam hukum pasar permintaan harus benar-benar diperhatikan sehingga apa yang diminta kastamer semestinya juga bisa dipenuhi, lebih-lebih jika customer mempersyaratakan diberlakukannya ISO. Dengan kata lain ISO bisa diinisiasi oleh customer terhadap produsen yang menyediakan jasa dan layanan produk. Jika tidak maka dia akan ditinggalkan. Tetapi akan lebih baik manakala ISO dimulai dari perusahaan sendiri tanpa harus menunggu pihak eksternal berteriak. Dalam sertifikasi ISO 


\section{Kuntarno Noor Aflah}

tidak ada sistem pemeringkatan seperti halnya akreditasi BAN-PT yang memiliki kualifikasi A, B, C (Fandy Tjiptono \& Anastasia Diana, 2003).

Proses untuk mendapatkan sertifikasi selama ini dianggap sebagai sesuatu yang susah. Sebetulnya mudah saja dan tak lama. Yang banyak memakan waktu sesungguhnya adalah proses persiapan yang dilakukan oleh perusahaan atau organisasi yang bersangkutan dikala menyiapkan data-data maupun dokumen-dokumen yang dibutuhkan dan akan diaudit.

Jika digambarkan dengan sederhana, perusahaan/lembaga yang akan diaudit manajemen mutunya, mereka mengajukan aplikasi kepada lembaga yang berhak mengeluarkan sertifikasi. Tahap berikutnya, kemudian lembaga standardisasi akan menilai apakah kinerja lembaga tersebut sudah apply dengan sistem yang dibutuhkan atau belum. Jika semua persyaratan sudah terpenuhi dan proses audit penilaian manajemen mutu sudah selesai maka sertifikat ISO akan diberikan.Proses ini biasanya hanya memakan waktu empat bulan. Namun manakala lembaga tersebut sudah menyiapkan data-data dan dokumen yang dibutuhkan untuk diaudit, maka waktu yang perlukan paling hanya butuh tiga minggu sampai satu bulan.

Ketika sebuah organisasi dilakukan audit pengawasan atau dalam istilah yang sering digunakan adalah 'audit ISO', sementara mereka sudah pernah mendapatkan sertifikasi, dan masih ada beberapa persyaratan lagi yang tidak bisa terpenuhi, maka hal itu bisa di-pending dengan membekukan sertifikasi sampai persyaratan dipenuhi kembali. Memang sejauh ini perusahaan yang banyak dibekukan adalah di negara Spanyol dan Jepang. Sedangkan di Indonesia justeru tidak pernah ada pembekuan sertifikasi ISO. Entah faktor apa 
yang mempengaruhi hal tersebut, penulis tidak begitu tahu. Namun kemungkinannya adalah karena tidak terlalu ketatnya aturan main yang digunakan. Adanya pelanggaran dan aturan yang longgar dan dapat ditarik kesana-kemari seperti karet; mungkin itu salah satu faktor penyebabnya.

\section{"Dilema" ISO Bagi OPZ}

Jika diterapkan pada organisasi pengelola zakat ISO, akan sangat membantu pemberi zakat akan lebih percaya bahwa lembaga yang sudah ber-ISO adalah lembaga yang betul-betul berkelas internasional. Dengan demikian selain meningkatkan kinerja, lembaga zakat ber-ISO juga bisa meningkatkan kepercayaan masyarakat (donatur). Apalagi belakangan ini makin banyak bermunculan lembagalembaga zakat. Belum lagi peristiwa bencana yang makin sering melanda sehingga banyak orang tergerak menyumbang. Kalau lembaga itu sudah dikenal memiliki sistem yang baik, apalagi telah mengadopsi standar internasional maka orang-orang pastinya lebih banyak memilih organisasi yang sudah ber-ISO. Berbeda dengan lembaga yang masih menerapkan sistem kekeluargaan atau sistem konvensional lainnya. Boleh dikatakan ISO bisa meningkatkan marketing image (Amin Widjaja Tunggal, 1993).

Meskipun demikian implementasi ISO terhadap sebuah perusahaan maupun organisasi tidak bisa menjadi jaminan lembaga tersebut bisa berkualitas. Sebab ISO sendiri adalah sistem yang memang tidak terlihat, tetapi dengan ISO perusahaan setidaknya maju satu langkah melakukan perbaikan. Namun acapkali ada perusahaan tatkala mengadopsi ISO kondisinnya lebih buruk dari pada sebelum disertifikasi. Faktor penyebabnya macam-macam bisa karena implementasi ISO yang tidak tepat sehingga membingungkan karyawan di dalamnya atau karena 


\section{Kuntarno Noor Aflah}

kehadiran ISO tersebut yang dianggap sebagai 'sesuatu yang ngribetin'.

Pengalaman pribadi penulis, yang sekaligus pernah menjadi auditor internal, saat bekerja di BAZNAS dan Baitulmaal Muamalat (BMM) (salah satu LAZ tingkat nasional), ketika hendak diaudit, lembaga selalu super sibuk. Bekerja hingga larut malam dan lembur di hari libur merupakan pemandangan yang biasa ketika lembaga mau diaudit ISO. Kegiatan seperti itu menuntut konsentrasi dan persiapan yang menyita banyak waktu, pikiran, tenaga dan menguras emosional.

Tetapi tidak sedikit perusahaan yang telah ber-ISO juga bisa menggenjot prestasi. Jadi ada perusahaan atau organisasi yang tambah baik, akan tetapi setidaknya dengan ISO itu perusahaan atau organisasi punya kerangka kerja yang jelas, sehingga mudah melakukan diagnosa segala permasalahan yang dihadapi oleh perusahaan atau organisasi.

Ada juga yang mengatakan bahwa hasil ISO semestinya linear dengan produktifitas dan peningkatan kinerja, karena ISO sendiri adalah terkait dengan improvement, atau lebih tepatnya adalah continual improvement, perbaikan berkelanjutan. Tetapi ada juga yang mengatakan bahwa ISO tidak selamanya harus linear dengan produktifitas, sebab produktivitas itu dapat juga dipengaruhi oleh banyak faktor. Meskipun demikian, biasanya perusahaan yang memiliki sertifikasi ISO setidaknya akan mengalami peningkatan performance dan positive brand. Oleh sebab itu hal terpenting bagi lembaga yang sudah menerima sertifikat baik BAZNAS maupun LAZ adalah adanya perbaikan berkelanjutan. Bukan hanya perbaikan pada saat menjelang diaudit ISO tapi juga perbaikan secara terus menerus usai diaudit ISO. 
Bagi lembaga yang akan mengajukan audit ISO, mereka biasanya terlebih dahulu menggandeng konsultan sebagai pihak yang mendampingi pra dan pasca ISO. Adanya konsultan ini dimaksudkan untuk memastikan lembaga yang akan diaudit apakah semua kebutuhan audit sudah disiapkan secara baik dan benar ataukah belum, inilah fungsi dan keberadaan konsultan (Noor Aflah, 2010).

Bagi lembaga konsultan sendiri, mereka juga menghendaki tak hanya berhenti setelah kliennya mendapatkan sertifikat ISO. Karena yang terpenting dalam ISO adalah bagaimana di internal organisasi itu sendiri, apakah nilai-nilai dalam ISO bisa diterapkan atau tidak. Jika Badan Sertifikat hanya 2 hari saat mengaudit lembaga, tapi untuk membangun sebuah komitmen itu butuh waktu dan komitmen, untuk merubah pola pikir seluruh pihak yang ada di lembaga tersebut. Sehingga bisa dibilang bahwa penerapan ISO penekanannya lebih ke internal organisasi. Kalau internalnya bagus, sebuah organisasi ketika mau dicek oleh badan sertifikasi dua hari atau satu hari tidak perlu mereka bingung, mereka siap, karena pada intinya pelaksanaan audit ISO adalah untuk memastikan apakah yang tertulis dengan yang dikerjakan sudah sinkron atau belum, apakah konsisten atau tidak dalam realitanya, tidak jauh dari proses seperti itu. Seperti komitmen dalam ISO, yaitu "tulis yang kamu kerjakan, kerjakan yang kamu tulis".

\section{Standardisasi pengelolaan zakat dunia}

Pada tahun 2012 yang lalu ada pertemuan internasional yang sangat penting terkait dengan perkembangan dunia perzakatan global ke depan, yakni Muktamar Zakat Internasional IX yang berlangsung di Amman, Yordania pada tanggal 26-28 November 2012. Forum ini adalah forum rutin dua tahunan yang melibatkan badan-badan zakat resmi negara-negara anggota OKI. Pada mulanya, forum yang pertama kali dilaksanakan di Kuwait 


\section{Kuntarno Noor Aflah}

tahun 1984 tersebut hanya dikhususkan untuk negaranegara Timur Tengah. Namun pada perkembangannya, muktamar tersebut diperluas ke belahan dunia lainnya, sehingga mencakup seluruh negara OKI. Indonesia sendiri baru bergabung pada tahun 2010 lalu di Beirut, Lebanon, saat berlangsungnya muktamar kedelapan, sehingga praktis keikutsertaan pada pertemuan Amman merupakan kali kedua (www.ekonomiislami.com)

Irfan Syauqi Beik, salah satu peserta utusan dari Indonesia menuliskan, dalam usulannya sektor keuangan syariah yang akan dikembangkan tidak hanya mencakup perbankan syariah saja, melainkan diperluas kepada seluruh lembaga keuangan syariah non bank, seperti asuransi syariah dan pasar modal syariah, hingga lembaga keuangan mikro syariah, zakat dan wakaf. Dimasukkannya zakat dan wakaf dengan pertimbangan bahwa kedua sektor ini merupakan pilar utama Islamic social finance yang memiliki potensi yang sangat besar.

Dari pertemuan itu, ada tujuh aspek yang menjadi fokus standarisasi ini. Ketujuh hal tersebut adalah: (i) standarisasi regulasi dan aturan perundang-undangan, (ii) standarisasi pihak yang menjadi otoritas zakat, (iii) standarisasi penghimpunan zakat, (iv) standarisasi penyaluran zakat, (v) standarisasi good amil governance, (vi) standarisasi pelaporan dan pertanggungjawaban, serta (vii) cross-sector activities atau aktivitas lintas sektoral.

Pada aspek yang pertama, ada tiga model regulasi yang berkembang saat ini, jika ditinjau dari ada tidaknya UU Zakat serta wajib tidaknya zakat dari sudut pandang hukum positif (wajib siyasi). Jadi bukan hanya menjadi kewajiban agama (wajib syari). Ketiga model tersebut adalah model komprehensif, model parsial, dan model sekuler. Dalam model komprehensif, negara telah memiliki UU Zakat secara khusus, yang mengatur seluruh aspek 
perzakatan secara detil, serta telah mewajibkan rakyatnya yang termasuk kelompok muzakki untuk menunaikan kewajiban zakatnya. Jika tidak, maka ada ancaman sanksi, baik yang sifatnya pidana dan atau sanksi administratif. Sedangkan pada model parsial, negara telah memiliki UU Zakat, namun belum mewajibkan rakyatnya untuk membayar zakat secara hukum positif. Biasanya pada model ini, UU Zakat lebih menitikberatkan pada aturan mengenai pengelola zakat atau institusi amil. Adapun pada model sekuler, tidak ada UU Zakat yang berlaku, dan pengelolaan zakat diserahkan sepenuhnya pada masyarakat (www.ekonomiislami.com)

Agar standarisasi ini bisa berjalan dengan baik, menurut Irfan Syauqi Beik, maka harus diupayakan agar setiap negara anggota OKI bisa mengembangkan model komprehensif. Model ini menjamin adanya proses integrasi yang kuat antara zakat dengan kebijakan fiskal dan perekonomian secara menyeluruh.

Selanjutnya pada aspek yang kedua, perlu ada definisi yang jelas mengenai otoritas zakat. Sama dengan sektor moneter dimana definisi otoritas sektor ini adalah bank sentral, meski di beberapa negara, sebagian kewenangan bank sentral diberikan pada pihak lain, yaitu otoritas jasa keuangan atau FSA (Financial Services Authority). Ini menjadi hal yang sangat penting (www.ekonomiislami.com).

Pada aspek berikutnya, definisi muzakki dan harta obyek zakat harus distandarisasikan sehingga setiap negara memiliki persepsi yang sama. Misalnya, meskipun muktamar zakat internasional telah memutuskan legalnya zakat profesi, namun di beberapa wilayah masih ada penolakan terhadap zakat profesi akibat minimnya sosialisasi dan edukasi. Sehingga, ada orang kaya muslim yang masuk kategori muzakki, dan ada orang kaya muslim 


\section{Kuntarno Noor Aflah}

yang tidak menjadi muzakki karena profesinya tidak ada dalam nash, seperti konsultan keuangan dan pengacara. Standarisasi ini penting agar persepsi umat ini bisa sama.

Demikian pula pada aspek berikutnya, yaitu penyaluran. Standarisasi ini sangat penting agar setiap negara memiliki panduan yang jelas, sehingga dapat meminimalisir kemungkinan terjadinya moral hazard. Misalnya, menyalurkan zakat pada lembaga keuangan mikro syariah (LKMS), tapi oleh LKMS tersebut dana yang ada disalurkan kembali dalam bentuk pembiayaan kepada perusahaan-perusahaan yang tidak masuk ke dalam kelompok usaha mikro milik mustahik. Ini tentu tidak sesuai dengan syariah. Standarisasi ini harus melahirkan guideline yang jelas terkait dengan program konsumtif dan program produktif, serta prioritas program yang harus dilakukan.

Dua aspek terakhir adalah good amil governance (GAG) dan aktivitas lintas sektoral. Pada GAG, hal yang sangat penting antara lain adalah standarisasi kode etik amil, serta mekanisme reporting dan auditing yang sesuai syariah dan menjamin transparansi dan akuntabilitas lembaga zakat. Sedangkan aktivitas lintas sektoral merupakan bentuk sinergi antar instrumen dan institusi keuangan syariah, seperti kerjasama antara perbankan syariah, pasar modal syariah, BMT dan lembaga zakat dalam mengentaskan kemiskinan dan meningkatkan kesejahteraan masyarakat.

Perlu ada panduan yang jelas agar masing-masing institusi tidak saling mengambil peran yang lain. Contoh, ketika zakat dikelola bank syariah, maka framework-nya menjadi berbeda dengan ketika zakat tersebut dikelola oleh badan/lembaga amil zakat. Seharusnya, zakat bank syariah diserahkan sepenuhnya pada lembaga zakat, namun pada sisi pemanfaatannya bisa disinergikan dengan program 
yang dimiliki bank syariah tersebut. (www.ekonomiislami.com)

\section{BAZNAS dan LAZ yang Ber-ISO}

Selama ini sudah banyak organisasi pengelola zakat, baik BAZNAS maupun LAZ yang sudah mendapatkan sertifikat ISO. Dalam pantauan penulis, mereka yang sudah mendapatkan sertifikat ISO dalam bidang manajemen mutu kinerja ini, yaitu ISO 9001: 2015 terdiri BAZNAS (www.pusat.baznas.go.id), Dompet Dhuafa (www.dompetdhuafa.org), Rumah Zakat (www.rumahzakat.org), Baitulmaal Muamalat (www.baitulmaalmuamalat.org, Baitulmaal Hidayatullah (www.bmh.or.id), NU-Care Lazisnu, PKPU (www.pkpu.or.id), dan masih banyak lagi.

Mereka yang sudah mendapatkan sertifikat ISO menurut pemantauan penulis yang pernah bekerja sebagai Pelaksana Harian Forum Zakat (FOZ), memiliki kinerja yang baik. Dilihat dari segi aktifitas penghimpunan dan pendayagunaan zakat, infak, shadaqah mengalami inovasi dan kreasi yang bervariasi. Penghimpunan zakat dari waktu ke waktu juga cenderung mengalami peningkatan. Hal ini menunjukkan bahwa ISO berpengaruh positif bagi peningkatan kinerja BAZNAS dan LAZ.

\section{Meretas Jalan Alternatif: "ISO versi OPZ"}

Berawal dari semangat ingin meningkatkan mutu bagi BAZNAS dan LAZ di Indonesia, sekaligus semangat dalam rangka self assesement, tahun 2008, FOZ (Forum Zakat) sebagai asosiasi organisasi pengelola zakat Indonesia, melakukan satu terobosan baru dengan mmembentuk tim untuk menerbitkan buku standarisasi mutu dalam rangka peningkatan manajemen mutu Organisasi Pengelola Zakat. Upaya ini dilakukan sebagai langkah mandiri melakukan penataan kualitas kelembagaan zakat di Indoensia secara 


\section{Kuntarno Noor Aflah}

bersama-sama antar anggota di Forum Zakat. Mengingat pada saat itu dari pihak pemerintah belum melakukan upaya dan langkah seperti ini. Sementara lembaga zakat sudah sangat mendesak untuk membuat panduan buku standarisasi manajemen mutu bagi lembaga zakat.

Hal ini sejalan dengan Cetak Biru Perzakatan Indonesia yang diterbitkan FOZ tahun 2012, bahwa salah satu pilar penting dalam cetak biru tersebut adalah adanya Standarisasi Manajemen Mutu bagi OPZ di Indonesia. Begitu juga singkron dengan Arsitektur Zakat Indonesia, baik yang disusun oleh Noor Aflah (Noor Aflah, 2010 ) maupun yang dibuat oleh IMZ (Nana Mintarti, dkk, 2011). Selanjutnya tim yang dibentuk FOZ bekerja secara bersama menyusun buku standarisasi mutu tersebut. Penulis yang ditunjuk sebagai Sekretaris Tim sekaligus merangkap anggota, merasakan beratnya menyusun buku ini. Bersamasama dengan anggota tim lainnya bekerja secara sungguhsungguh dalam kurun waktu yang tidak sebentar. Butuh waktu lebih dari dua tahun untuk dapat melahirkan dan menerbitkan buku yang standarisasi mutu tersebut.

Akhirnya pada tahun 2011 lahirlah buku standarisasi manajemen mutu bagi Organisasi Pengelola Zakat berjudul "Zakah Criteria for Performance Exellence; Pedoman Kriteria Zakat untuk Kinerja Unggul"

\section{Buku "ISO ala OPZ" bernama Zakah Criteria for Performance Exellence}

Lahirnya buku Zakah Criteria for Performance Exellence merupakan berkah tersendiri bagi BAZNAS dan LAZ di Indonesia. Mengapa demikian, karena selama ini belum ada buku standarisasi manajemen mutu yang dibuat untuk menata mutu kelembagaan zakat di Indonesia. Ahmad Juwaini, yang saat itu sebagai Ketua Umum Forum Zakat, dalam sambutannya memberikan apresiasi yang setinggi- 
tingginya bagi tim yang telah menyusun buku ini ( $M$. Surjani Ichsan, 2011: vi).

Menurut M. Surjani Ichsan, selaku Ketua Tim penyusun, mengatakan dengan berpedoman pada buku ini BAZNAS dan LAZ di Indonesia dapat meningkatkan performance organisasinya. Organisasi pengelola zakat sebagai organisasi nirlaba yang unik dan spesifik dengan berbagai aturan syariah mempunyai kondisi dan situasi yang spesifik dalam pengaturan keorganisasian dan manajemennya. Oleh karena itu pengelolaan aktifitas perzakatan perlu mendapatkan standar bagaimana mengelola secara profesional dan sesuai syariah, dan buku inilah yang sesuai dengan karakteristik BAZNAS dan LAZ di Indonesia. Buku pedoman ini berupaya memberikan langkah dan deskripsi pengelolaan kinerja sebuah organisasi tidak hanya bermutu tingkat nasional melainkan hingga bermutu hingga bertaraf international (M. Surjani Ichsan, dkk, 2011, vii)

Buku tersebut mengacu pada teori Malcolm Baldrige (MB) yang ditemukan oleh Jack Welch. Teori ini pertama kali dikenalkan di Amerika Serikat. M Surjani Ichsan, sebagi ketua tim penyusun, menyakini bahwa teori yang dituangkan dalam buku tersebut lebih komprehensif dari pada menejemen mutu yang ditawarkan oleh ISO dan sejenisnya. Karena dengan menggunakan teori tersebut, sebuah organisasi akan dapat mengidentifikasi kekuatankekuatan dan kesempatan-kesempatan untuk perbaikan dari berbagai area dalam organisasi. Terutama yang berkaitan dengan kepemimpinan, perencanaan strategis, fokus pada pasar (dalam kaitannya dengan lembaga zakat adalah muzaki, mustahik dan stakeholder), pengukuran, analisis dan manajemen pengetahuan, fokus pada sumberdaya manusia, manajemen proses dan hasil-hasil (Vincent Gasperz, 200). 


\section{Kuntarno Noor Aflah}

Yang menjadi sasaran dalam buku tersebut adalah sebanyak 7 kriteria yaitu pertama Leadership, kedua, Strategic Planning, ketiga, Focus on Muzaki and Mustahik, keempat, Measurement, Analysis, and Knowledge Management, kelima, Amilin Focus, keenam, Process Management, ketujuh, Results. Ketujuh kriteria dalam buku ini semuanya bisa diterapkan di organisai pengelola zakat. Namun jika BAZNAS dan LAZ belum bisa menerapkan seluruh kriteria yang ada dalam buku ini, minimal bisa mendefinisikan ketujuh kategori tersebut secara sederhana. Jangan sampai organisasi pengelola zakat tidak bisa mendefinisikannya. Karena kalau tidak bisa mendefinisikan berarti organisasi itu tidak akan berkembang apalagi maju.

Setiap item bermuatan filosofis yang penuh makna. Misalnya tentang pentingnya kepemimpinan. Kepemimpinan yang visioner ibarat sebuah perahu (organisasi pengelola zakat) yang berada di tengah turbolensi gelombang globalisasi. Sebuah perahu yang berada di tengah-tengah berbagai macam ancaman. Seperti badai, karang yang besar, gelombang yang tinggi, arus yang deras dan ikan besar yang berbahaya. Kalau pemimpin tidak bisa mengendalikan perahunya. Tidak mampu menyatukan kekuatan-kekutan yang ada di awak kapal akhirnya satu demi satu tantangan itu menjadi hambatan yang berbahaya.

Dalam rangka menjaga mutu dan kinerja OPZ tidak hanya dari sudut pandang amil sebagai lembaga atau personil yang mengelolanya, tetapi juga mencari masukan dari sudut pandang muzaki, mustahik, masyarakat dan pemerintah, sebagai stakeholder dalam lingkup lembaga zakat, karena sebuah lembaga zakat harus mempertimbangkan masukan dari berbagai pihak. Di antaranya mempertimbangkan semua fungsi dan karakteristik program dan layanan organisasi. Semua bentuk akses dari atau ke pelanggan (Muzaki, Mustahik, 
Pemerintah dan Masyarakat) yang telah memberi kontribusi yang bernilai seperti cara mendapatkan muzaki, mustahik, kepuasan muzaki, mustahik, masyarakat dan pemerintah, memberi preferensi, memelihara mereka dan menciptakan loyalitas kepada mereka, semua harus dibuka aksesnya (M. Surjani Ichsan, dkk, 2011).

Di dalam buku ini, program dan kegiatan OPZ ditekankan harus berorientasi pada kepentingan muzaki dan mustahik dengan cara menyediakan jasa layanan yang sesuai dengan keinginan muzaki dan mustahik, mampu menciptakan jasa layanan yang unik, yang tidak ditawarkan pesaing semisal lembaga philantropi atau lembaga zakat lainnya. Diferensiasi dapat berupa tawaran program dan ide baru, modifikasi yang sudah ada, kombinasi jasa yang ditawarkan, customization yang ditawarkan, memperbanyak mekanisme akses, respon yang cepat dan hubungan kemitraan yang khusus.

Di samping itu, buku ini juga memberikan arahan bahwa OPZ harus memiliki sensitivitas yang konstan terhadap permintaan muzaki, mustahik, masyarakat dan pemerintah setempat dan tuntutan kebutuhan yang dinamis. Di samping itu, OPZ harus mempunyai kemampuan mengantisipasi perubahan pangsa pasar, kesadaran dan kesiapan menghadapi kemajuan teknologi dan keunggulan OPZ lain.

\section{Nilai dasar dan konsep berbasis ayat Alquran}

Buku pedoman ini disusun berdasarkan keterkaitan antara nilai-nilai dasar dan konsep yang digali dari ayatayat Alquran dan hadis Nabi. Ada 9 nilai dasar dan konsep dalam buku ini, terdiri; Kepemimpinan Visioner, Keunggulan yang Digerakkan Kastamer, Pembelajaran Organisasi dan Personal, Penghargaan Terhadap Kinerja, Kegesitan dan Kesederhanaan, Kemampuan Berinovasi, Fokus pada Masa Depan dan Tanggungjawab Kepada 


\section{Kuntarno Noor Aflah}

Publik, Fokus Pada Hasil dan Penciptaan Nilai, dan Perspektif Sistem.

Ayat dan hadis yang diambil disesuaikan dengan kandungan yang ada pada nilai dasar ini. Sebagai contoh ayat yang berkaitan dengan nilai dasar pertama; Kepemimpinan Visioner. Ayat yang sesuai dengannya adalah QS Al-Anbiya: 73 dan hadis riwayat Abu Naim yang artinya "Pemimpin suatu kaum adalah pengabdi (pelayan) mereka" (HR Abu Naim), dan hadis yang artinya "Semua kamu adalah pemimpin dan bertanggungjawab atas kepemimpinannya" (HR Bukhori \& Muslim).

Nilai dasar lainnya yang sangat cocok dengan karakter lembaga zakat adalah Kegesitan dan Kesederhanaan (Agility \& Simplicity). Sebagai lembaga sosial kegamaan, lembaga zakat dituntut untuk gesit menghadapi situasi yang berkembang dan lincah dalam merespons perubahan, namun tetap harus dalam koridor kesederhanaan. Sederhana dalam arti tidak bermewah-mewahan dan menggunakan dana tanpa mempertimbangkan asas manfaat dan kepatutan. Nilai dasar ini sesuai dengan ayat Al-Quran Surat Al-Muddatstsir: 1-2, Surat Al-Insyirah: 7, dan Surat AlSyu'ara': 215.

Dilihat dari sisi aspek-aspek yang dibahas dalam manajemen mutu versi OPZ yang ada dalam buku ini, terdapat perbedaan-perbedaan yang mendasar dibanding dengan versi lainnya, terutama versi ISO. Menurut buku ini, aspek-aspek dalam ISO dibahas dalam satu kriteria, yaitu kriteria keenam; Process Management. Sedangkan enam aspek lainnya tidak dibahas dalam ISO. Hal lainnya yang tidak dibahas dalam ISO adalah Profil Organisasi. Bagaimana Profil Organisasi dibuat dan diterapkan di sebuah organisasi, tidak dibahas dalam ISO. Sedangkan di dalam buku Zakah Criteria, dibahas secara mendalam. 
Terakhir, perbedaan mendasar terlihat pada nilai dasar dan konsep buku ini yang berbasis pada Alquran dan hadis Nabi. Hal ini menunjukkan bahwa setiap aspek dalam operasionalisasi lembaga zakat selalu dipandu dengan nilainilai yang terkandung dalam Alquran dan hadis Nabi. Dengan demikian, kinerja lembaga zakat yang dipandu dengan ayat Alquran dan hadis Nabi akan dapat terhindar dari kesalahan-kesahan prosedural. Manajemen mutu yang diperoleh lembaga zakat akan mendapat keberkahan karena menjalankan aturan-aturan yang ada dalam Alquran dan hadis Nabi.

\section{Simpulan}

Dari pembahasan di atas dapat disimpulkan bahwa manajemen mutu bagi organisasi pengelola zakat sangat penting dimiliki. Setiap organisasi perlu menerapkan manajemen mutu secara baik dan benar serta konsisten antara yang ditulis dengan yang dilaksanakan. Model manajemen mutu yang dipakai bisa disesuaikan dengan kebutuhan masing-masing organisasi. Apakah menggunakan ISO 9001: 2015 seperti yang sudah digunakan oleh BAZNAS dan beberapa LAZ besar di Indonesia, atau memilih lainnya.

Jenis standarisasi manajemen mutu khusus organisasi pengelola zakat sudah disusun dan disiapkan dalam bentuk buku Zakah Criteria for Performance Exellence. Buku ini cocok digunakan oleh BAZNAS dan LAZ. Tujuh kriteria yang ada dalam buku ini memandu organisasi untuk mengidentifikasi kekuatan-kekuatan dan kesempatankesempatan untuk perbaikan dari berbagai area. Terutama yang berkaitan dengan kepemimpinan, perencanaan strategis, fokus pada pasar, pengukuran, analisis dan manajemen pengetahuan, fokus pada sumber daya manusia, manajemen proses dan hasil-hasil. 


\section{Kuntarno Noor Aflah}

Manajemen mutu versi OPZ memiliki kerangka dan prinsip dasar yang berbeda dengan lainnya. Ayat-ayat AlQuran dan hadis Nabi menjadi landasan di dalam prinsip dasar dan kerangka manajemen mutu ini. Tentu semakin mempertegas adanya perbedaan mendasar bahwa manajemen mutu OPZ dilandasi nilai-nilai yang terkandung dalam Al-Quran dan hadis Nabi, dengan harapan aktifitas dalam pengelolaan zakat mendapatkan berkah dan tetap berkualitas baik.

\section{Daftar Pustaka}

Amin Widjaja Tunggal, Manajemen Mutu Terpadu Suatu Pengantar (Total Quality Manajement), Rineka Cipta, Jakarta, 1993.

Didin Hafidhuddin, Manajemen Pengelolaan Zakat di Indonesia, FOZ, Jakarta, 2012.

Fandy Tjiptono \& Anastasia Diana, Total Quality Management, (edisi revisi), Andi Offset, Yogjakarta, 2003.

Jenny Waller, dkk. The Quality Management Manual: How to Write and Develop a Successful Manual for Quality Management Systems, Edisi terjemah, Pustaka Binaman Pressindo, Jakarta, 1994.

Kuntarno Noor Aflah, Optimalisasi Pengumpulan Dana Zakat Melalui Pendirian UPZ (Makalah, 2018)

M. Surjani Ichsan, dkk, Zakah Criteria for Performance Exellence; Pedoman Criteria Zakat untuk Kinerja Unggul, FOZ, Jakarta, 2011.

Majalah INFOZ, edisi September 2012 
Nana Mintarti, dkk (Ed), Menggagas Arsitektur Zakat Indonesia; Menuju Sinergi Pemerintah dan Masyarakat Sipil dalam Pengelolaan Zakat Nasional, Cet ke-1, Indonesia Magnificence of Zakat dan PEBS FEUI, Jakarta, 2011.

Noor Aflah (ed), Arsitektur Zakat Indonesia; Dilengkapi Kode Amil Zakat, UI Press, Jakarta, 2010.

Noor Aflah, Strategi Pengelolaan Zakat di Indonesia, FOZ, Jakarta, 2010.

Syahu Sugian O, Kamus Manajemen (Mutu), PT Gramedia Pustaka Utama, Jakarta, 2006.

Tim Penyusun, Standar Mutu ISO 9001:2015; Sistem Manajemen Mutu - Persyaratan, Cognoscenty Consulting Group, tt.

Tim Penyusun, Training The Concept of Quality and Introduction to ISO 9001:2015 Standard, (Modul, Dynamic Consultant Jakarta, tt.

Vincent Gaspersz, GE Way And Malcolm Balgrige Criteria for Performance Exellence ; Mengungkap 25 Rahasia Kepemimpinan Jack Welch, Mantan CEO General Electric yang Menjadikan GE Perusahaan Nomor Satu Dunia yang Paling Kompetitif, Gramedia Pustaka Utama, Jakarta, 2007.

Vincent Gaspersz, Total Quality Management, Gramedia Pustaka Utama, Jakarta, 2008.

www.alimansur.wordpress.com

www.ekonomiislami.com 